\title{
CIRCULAR ECONOMY, HUMAN BEHAVIOR AND LAW
}

\author{
ALEXANDRE MORAIS DA ROSA \& ANA LUISA SCHMIDT RAMOS \\ Universidade do Vale do Itajaí (UNIVALI), Brazil
}

\begin{abstract}
Our intention with this article is to analyze the possibilities of the creation of mechanisms through the legal system that will induce the appropriate behavior to the effectiveness and expansion of the premises of the circular economy. Based on the microeconomics assumption that agents are optimizing subjects, the normative creation of fines and benefits in the face of the adoption of a pattern of behavior related to the circular economy is the challenge. At the same time that the action can be observed from the individual point of view, the creation of homologating bodies of sustainable practices by corporations, with the accreditation of these behaviors of eco-consumption, industrial ecology, economic functionality and reuse, stands out. The focus of the article will be the possibility of water management that, although public, must be worked on in order to understand the water market. The choice of water comes from the fact that it is a necessary condition for human survival for the present and the future generations. In this sense, the State has a leading role that, nevertheless, transcends territorial boundaries, requiring that international agreements be established in order to uniform mechanisms for accreditation of promoted practices, fines and benefits arising the adherence to the circular economy movement. The proposal is to indicate the design of culturally acceptable mechanisms of sanctions and benefits capable of inhibiting and encouraging the behavior of state, private and corporate agents.

Keywords: circular economy, water, normalization, individual optimizer, state agent.
\end{abstract}

\section{INTRODUCTION}

Rationally, one has the notion that too much exploitation of natural resources is an announced tragedy. The water is a natural resource essential to human survival on the planet, as well as to the movement of the economy, therefore it must be rationalized for the next generations [1]. Circular economy, an alternative to the classic model of linear production and consumption, is a sustainable economic concept, founded on the principle of closing the life cycle of resources, products, services, waste and materials, which has been implemented in several sectors, including water use/reuse. However, the transition to this new model requires the assumption that the individual is an agent for optimizing costs and benefits. This circumstance must be considered by the State in its role of protagonist in the establishment of mechanisms that aim at adherence to the movement of the circular economy, both by State agents, private and corporate.

To achieve the proposed goal, the approach is divided as follows: 2 Sustainability; 3 From the linear model to the circular economy; 4 The optimizing individual, 5 Sustainability, the action of the State and the Tragedy of the Commons.

It was used the inductive method with bibliographical research for the development of the work and, consequently, the elaboration of files from the operational concepts and categorization.

\section{SUSTAINABILITY}

The pollution and the scarcity of resources from industrialization and urban growth - from rampant extraction and consumption - have been the subject of global concern and debate since at least the early 1970s. From the idea of an environment with infinite resources and unlimited, the idea of sustainability was gradually implemented [2]. 
This logic is manifested by the overexploitation of resources that serve as input to industry. Increasing demand means that companies seek to reduce input costs and preservation can rise costs, which is why the claim to optimize efficiency disregards the logic of sustainability. The discourse of sustainability depends on the attitude of adherence of the managers, often implying in the increase of the costs of production and, consequently, in the reduction of the competitiveness. New strategies will then have to be sought [23].

It has been observed the scarcity of non-renewable natural resources, such as oil, copper, cobalt, lithium, silver, lead and tin, vital commodities to the growth of the modern economy [3]. The cost of extraction and the production chain must be internalized in the price, which is why the improvement of management efficiency causes the relationship between humans and the environment to change. Previously the exploration kept the vision of future survival, making the land management to be at feasible levels and able to sustain the life in the place. The exploitation process deteriorates this relationship and promotes more individualistic action, losing control over the limits and effects of pollution. The effects can be direct, impeding the continuity of the activity, as indirect, in the modality of negative externalities and whose dimension is not cognitively verifiable in the first moment. It will be the accumulation of production, the reduction of land productivity and the deleterious effects on productivity that will be seen in the future (erosion and poor soil, water pollution, reduction of the diversity of fauna and flora). The dilemma is set in the face of increased production efficiency with increased natural exploration, without the ability to automatically restore nature, taken as if it were free. Although natural resources are of universal access, they lose quality and quantity, and mechanisms of collective protection must be established as the challenge of the future [22].

With the water, a natural resource essential to human survival, it was not different. Although the surface of the planet consists of 30 percent of land and 70 percent of water, it is known that of these 70 percent, 97 percent correspond to salt water and only 3 percent of fresh water. In addition, 69 percent of the fresh water volume of the land is in ice in the polar ice caps and glaciers, 30 percent is groundwater and only 1 percent is water available on the surface [4].

In addition, given the geographical and climatic peculiarities, the water distribution is not uniform. The regional imbalance in the water division is strengthened in the face of poverty and the different urban and industrial concentrations. It also suffers from the effects of overexploitation and pollution, especially in peripheral countries. It is not enough to have access to water since quality is important to avoid diseases and negative externalities. Potable water, therefore, in the face of human impermanence, requires the awareness of its essential importance, with the stipulation of a minimum access to survival, in a conscious and democratic way. It should be added that the increase in population and the demand for food leads to an increase in the consumption of water, which, lacking recomposition mechanisms, becomes increasingly scarce [4].

Alongside the so-called Smart Cities, there are movements to make agriculture and industry equipped with intelligent policies and mechanisms to control, preserve and consciously distribute water. These are initiatives that seek to foster conscious practices and habits about the water cycle and its collective importance, especially when predictions of increasing world population will require new levels of availability of water resources, within the logic of circular economy. There should be a co-ordination of initiatives, fomented and imposed by the Government - but not only it - capable of reorienting the way in which the use of the natural water resource is promoted. Convergent attitudes and behaviors constitute a condition for the possibility of future and sustainable life [4]. 
It is estimated that by the year of 2050 , more than 40 percent of the world's population will live in areas of extreme water shortage [3]. Looking at his background, from the 1970s and 1980s, environmental protection measures were adopted through conventions and deliberations of international organizations [5]. The Club of Rome Reports on the limits of growth, for example, exerted great influence in the convening of the 1972 United Nations Conference in Stockholm, and are mentioned by many as precursors of Environmental Law [6]. Prior to this, in 1969, the United States adopted the National Environmental Policy Act, which includes the requirement for certain actions to carry out the Environmental Impact Study and is regarded as the first properly legal environmental institution [6].

The future concerns, as it does human survival itself on the planet. In 1987, based on the Brundtland Report - Our Common Future - drawn up by the UN World Commission on Environment and Development [7], emphasized the negative consequences of poverty on the environment [8] and sustainable development was conceptualized as one that meets the needs of the present without compromising the possibility of future generations to meet their own needs [7].

The idea of maintaining a minimum capable of fostering the lives of future generations lies at the foundation of the Report's principles, policies and guidelines, always focused on guaranteeing collective fundamental rights, on the stormy relationship between humans and nature. In this sense, three factors stand out: modulation of the rate of extraction and exploitation of natural resources; establishment of a level capable of promoting renewal; pollution control in order to allow ecological assimilation. Therefore, the meaning of growth is no longer merely economic, but questions of survival are inserted, failing to follow the tragedy of annihilation [22].

The concept evolved to a point that in 2002, at the United Nations Conference on the Environment in Johannesburg, or Rio +10 [7], the term sustainable development was replaced by the term "sustainability". The expansion of the list of elements linked to the idea of sustainability involves the ecological, social, economic, cultural and political factors, transforming the way interests are inter-interpreted and hierarchized. [7].

Although the content of declarations, as well as intentions, in the absence of mechanisms of coercive effectiveness, we continue to watch the disappearance of natural resources. The current generation witness's deforestation, the devastation of pastures, soil erosion, the melting of the polar caps, the advance of the deserts, with the effect of reducing drinking water, increasing pollution and poverty [22].

Overcoming immediate goals is increasingly pressing as negative effects - externalities no longer respect borders, requiring awareness that we are all interconnected and that the perspective must achieve global policies. However, faced with pressing objectives, the challenge of global and local agendas is increasing, capable of accounting for parallel sustainability strategies [22].

\section{FROM THE LINEAR MODEL TO THE CIRCULAR ECONOMY}

According to Gabriel R. Ferrer, all species change the environment in which they live to meet their needs, but man, by his immense physical and intellectual abilities, has the exclusive capacity to create new needs, which go far beyond mere subsistence [6]. The linear model of production and consumption, based on the extraction-transformation-use-elimination scheme, that is, on the principles of take, make, waste [3].

This model, however, is not sustainable. During the process, Mauricio Espaliat emphasizes, residues and by-products are originated and they end up returning to the 
productive cycle and to the natural cycle, but which are depreciated and destined to the elimination by incineration, destruction and deposit [4].

An alternative is the circular economy, a model considered as holistic, restorative and regenerative [4]. This economic concept, which emerged in the 1970s [4], is in line with sustainable development and aims to keep the value of products, materials and resources in the economy as long as possible and to minimize waste generation and waste of raw materials, water and energy [4]. It is a model that takes into account economic, environmental and social aspects and is based on the principle of closing the life cycle of resources, products, services, waste and materials [4].

Circular economy implies breaking with the assumptions of the traditional model of economics, precisely because it alters the meaning, place, and mode of resource utilization. Instead of considering them full and without cost, it promotes reading from the scarcity and costs. Changing the assumptions changes the sense of efficiency that is no longer considered in the face of production and costs, and also involves the management of waste lands, which, far from being waste, must be reinserted into the productive scale. The performance of the circular economy model precupes, values and the environmental impacts of production, broadening the approach focus and efficiency evaluation criteria [3].

It is worth emphasizing the three principles of the Circular Economy, consisting of: 1) preserving and improving natural capital, promoting initiatives for the preservation of finite reserves, with a privileged access to renewable resources, using technological resources to maintain natural capital; 2) To optimize incomes, seeking new modes and manufacturing, industrial design, recycling, etc., all linked to the intention to maintain the circularity of inputs, avoiding the entry of new natural resources; the optimization improves the ecological efficiency, acting in a dynamic and non-static way; 3) Reduction of negative externalities in the face of exploitation, i.e. the effects on third parties, directly or indirectly, through pollution prevention practices, reduction of reserves, etc. [3].

In regards to water, the circular economy is established with its reuse, becoming the one that was used in a new resource source [9]. Agriculture, for instance, although occupying 11 percent of the land surface, accounts for 70 percent of water extraction, a number that tends to increase with population growth [4]. The industry accounts for more than 20 percent of water demand, while power generation consumes 10 to 15 percent of available surface water [4].

Joaquin Melgarejo proposes that in the urban sector one can reuse water in agricultural irrigation, parks and gardens, and for cleaning [9]. In the industry, new products can be generated in refrigeration processes, among other applications [9].

\section{THE OPTIMIZING INDIVIDUAL}

As the classical linear model of production and consumption is being replaced by the circular sustainable economy, new challenges are emerging. One of them is the assumption - accepted by Microeconomics - that agents are optimizing individuals, whose actions are marked by immediacy and few concerns about the future [10].

The satisfaction of the immediate needs is the model by which one tries to understand the situation of the subjects in face of the Circular Economy. Concern is demanded of oneself and the other in a collaborative way, a situation that requires a change in the collective posture of the subject, incompatible with the presupposition of his selfish action. It posits itself to satisfy its well-being, little concerned with the effects towards others or even with it in the future. Perhaps it is the case to insert a new factor of understanding of homo economicus that walks to the tragedy. The rational economic agent, then, does not care about the issue of the 
Circular Economy, unless something is imposed and, in fact, makes embarrassment for adequacy [23].

The tendency of individuals in the cognitive level is not to value the aspects that can lead to tragedy, not because of lack of awareness, but because the effects are distant in time and there is no palpable evidence of cause and effect. Although we know of the deleterious effects, one differentiates something that is close to the chain of causality of what is distant [11].

From this point, then, it is followed to understand the interactions between optimizing (maximizing) individuals, both in private relations and in public relations. The Microeconomics [10] seeks to indicate the behavioral expectations of individuals (rational choice in the pursuit of utility maximization - Rational Choice Theory - TER) from the relation between ends (alternatives to each other) and means (of scarce resources) [12].

In regard to the sustainability discourse, the optimizing individual adopts a self-limited posture in face of the multiple possibilities of consumerism and overexploitation. The external influx by consumerism and destruction requires that the individual by him/herself adopts behaviors that impede the widespread maximization of its well-being, given the scarcity of natural resources. Hence the importance of State intervention by mechanisms to encourage circular economy and aversion to waste.

\section{SUSTAINABILITY, THE ACTION OF THE STATE AND THE TRAGEDY OF THE COMMONS}

The adoption of sustainable posture demands costs [13] and requires the State to act towards limiting the exploitation and the use of public and/or collective resources. Therefore, the metaphor of the Tragedy of Commons, created by Hardin [14], can help to understand the need for optimization of natural resources, serving as mechanisms for creating public policies capable of achieving sustainability. The analysis of the individual's behaviors generally does not take into account the sum of all conduits and the impact of the sum on the environment. The logic he presides over is that 'one more action will not make a difference' [15]; but it does. So, it is worth understanding what the Tragedy of the Commons means in the path to sustainability, precisely because garbage thrown in the street or a small polluting behavior, apparently irrelevant, becomes, on the whole, something deleterious.

The Tragedy of the Commons is a kind of social bottom-set trap, involving the paradox between unlimited individual interests and the use of finite resources. It states that free access and the unrestricted demand for a finite resource structurally condemn this resource because of overexploitation. In the face of the limited resources of the Environment and its inability to assimilate, behaviors that, in isolation, appear irrelevant, become another step towards the tragedy.

The cost of unsustainable conduct is assimilated by the collective [16]. Thus, given the lack of reflection on the subject, even because the cost of individual conduct seems to be irrelevant, it implies cumulative losses, because it is outsourced by other inhabitants of the planet. The awareness that the costs of unsustainable behaviors is internalized by the offender himself and also by the effect of other individual behaviors may be the necessary realization to leverage a more sustainable performance, since he may be able to understand the consequences of the consequences of their behaviors.

The picture of this situation can be very clear with respect to the use of water, both domestically, as well as in agriculture and industry. This is because the absence of a stipulation of responsibility, as pointed out by Coase [17] in The problem of social cost, can generate the excessive use. 
Hence it arises the problem of rational allocation of resources. Bierman and Fernandez presented an important example, whose premise is the Tragedy of the Commons. It consists of the experience of inviting a group of friends to watch a movie and serve a large bowl of popcorn. Collective ownership and lack of assurance of the amount of popcorn causes a run to the popcorn, even if one does not feel as much desire. It is evidence of the Coase Theorem in which the assignment and assurance of property helps the efficiency of the exchanges, reducing transaction costs. In the example of popcorn, the antecedent division of popcorn into small bowls makes the sense of ownership imply the highest respect and cooperation of the invited friends. Of course, if you eat popcorn alone you will have no problems, but when the theme comes up in community, whether with popcorn, with yogurt or even with natural resources, the absence of regulation, allocation, ownership, in line with the Tragedy of Commons, tends to make coexistence inefficient. Therefore, it is not only a question of preserver, but rather of seeking efficient mechanisms of allocation of natural resources that prevent overexploitation due to cognitive traps. The role of the third party organized and capable of imposing sanctions appears as a means of imposing a certain order on the empire of merely selfish interests [18].

A small change can change the action of the actors. Instead of a large bowl, is a small portion is distributed to each of the agents, the possibility of eating the popcorn calmly is greater.

The same is true of water. As subjects who optimize time and resources, it is not uncommon to spend 112 liters of water for washing dishes, 75 liters for shaving, 560 liters for washing the car with a hose, 18 liters for brushing teeth with an open faucet [1]. he consequence is that the loss of water in Brazil, for example, reaches 40 percent. Abusive exploitation of a common good can lead to collective tragedy.

The tragedy of the commons shows that the use of ordinary goods without cost [19] implicates in its abuse, given the maximization of its utility [20]. Hence, the management of an individual conduct apparently without economic cost - this fact does not enter into the calculation of individual decision making - can generate a collapse of the collectivity. Experience has shown that agents will waste common resources given the absence of cost. The comparison between social cost / benefit needs to be on the agenda at all times, inserting itself in the context of sustainability. The maximization of collective benefits, that is, efficiency, presupposes the strategic behavior of rational agents, a situation not verified at the present time, to the waning, it is true, of legal instruments and understanding of economic activity.

Each individual conduct, analyzed from the collective point of view, has a huge cost. The allocation of public and private resources implies reduction in other areas (rivalry in the use of scarce resources), that is, the explosion of non-sustainable conduits imposes externalities. The internalization of externalities, an interesting solution in the private sphere, is much more complex in the public field. In both cases, however, following Coase, it can be said that the creation of incentive mechanisms and aversion to unsustainable conduits is an efficient mechanism for resolving issues, provided that property rights are guaranteed, with costs and burdens.

The stable regulatory framework is therefore fundamental to the transition to the circular economy. The State has a leading role in establishing culturally acceptable mechanisms of sanctions and benefits that inhibit and encourage the behavior of state, private and corporate agents.

This role, however, transcends territorial boundaries and requires the promotion of international agreements that establish uniform mechanisms for accreditation of the practices promoted, fines and benefits arising from adherence to the circular economy movement. 
In addition to the regulation of international law, countries can create differentiated credit lines, bilateral agreements, for example, in which the imperative is the requirement of a certain standard of products from the Circular Economy, duly measured by external agencies. The entire rights protection guideline (Cite the below) goes into collaborative activity. The problem is that without coercion or with very fragile mechanisms of punishment, membership demands the articulation of parallel networks of countries adhering to the Circular Economy model. At first, this may mean losing global competitiveness, but it may be the way to implicate other countries in green examples [22].

The provision of the Vienna Treaty, when brought to environmental law can produce mechanisms of protection for both nature and humans. In this regard, The Rio Declaration on Environment and Development reaffirmed the need for States to guarantee the exploitation of their own natural resources while limiting exploitation to the guarantee to the healthy environment of other states and areas deprived of domination. some state. Somehow he acknowledged the possibility of negative externalities extra/ultra-territory of the country and, with this, broad possibilities of control and preservation. Thus, the neighboring States have a greater role to play, avoiding that they only witness the environmental degradation that has taken place beyond their borders. Cooperative mechanisms of monitoring and suprastate preservation are necessary. It should also be noted that Principle 18 of The Rio Declaration on Environment and Development has created cooperative mechanisms for information and contingency between States, requiring notification to other global partners. This acknowledges the transcendence of the possible effects of environmental emergencies, given, fundamentally, the recognition that the healthy environment is the right of all. With notification, countries can better schedule to tackle the effects, mitigating the risks and consequences of dangerous actions [22.]

The European movement to implement the Agenda 2030, for example, established 17 objectives and 169 goals to achieve sustainability. In December 2015 The European Commission (EC) adopted several initiatives in the documents of the economic package that deserve to be highlighted. Among them were several guidelines for Member States to produce legislation on the minimum amount of water reuse, with effects on the volume of natural resources not reused and also on the reusable use of irrigation in agricultural activity. All of these initiatives are part of the green water reuse agenda, and therefore of circular economy.

There are also other policy areas for the transition to the circular economy. ISO 9001 and ISO 14001, for example, guide processes related to quality and environmental management policies [4]. The European Eco-Management and Audit Scheme (EMAS), the EC Building Certification, the Building Research Establishment Environmental Assessment Methodology (BREEAM), the Leadership in Energy and Environmental Design (LEED), US Green Building Council (USGBC), and the Sustainable Building Certification (CES) are other examples [4].

It is true that the European regulatory landscape, for example, has been changing since 2009 , with the creation of several initiatives, among them taxation with taxes and also the stipulation of a market for the purchase and sale of carbon emissions, as well as waste, making the logic of sustainability gain mandatory force. With this, there is a concentrated effort in the harmonization of legal systems, with production and marketing controls capable of inhibiting the polluting effects and, somehow, aligning the public policies in the way of sustainability, via Circular Economy. The result is the birth of a new economic model, much more concerned with the principles of sustainability and able to mitigate the deleterious consequences of the old economic model. In the political agenda of the rulers and also entrepreneurs a new way of dealing with finite resource issues is consolidated, among them 
the hydro, whose purpose is to implement behaviors convergent to the preservation of the environment. The challenge is to broaden the incidence of the circular economy model beyond the local and make a global policy. The UN has a leading role in promoting public policies, especially by funding adequate positions in regions dependent on external and international aid. A global scheme gains green and sustainable contours [3].

In order for circular economy policies to be more effective, however, there is a growing need for innovation in political, economic and financial strategies, with the aim of fostering transitional agendas, recognizing, certifying and validating can represent a step forward toward circular economy-based businesses. Therefore, the state function of mediating the increase in production costs must be parallel to the imposition of sanctions on enterprises that resist conforming to the new model. State power is a decisive factor, even if it represents an increase in the cost of production. It is the choice of priorities based on the circular economy that depends on the sustainable future [3].

Of course, the implementation of a true economy must be articulated in short, medium and long-term schemes with guarantees and transparency. Businesses and capital need security in risk assessment. In this way, access to new technologies needs to have mechanisms of priority to those already linked to the green movement, otherwise it will punish those who have previously joined. At the same time, it must use strategies capable of seducing new companies that have lagged behind, otherwise it will not be possible to turn green. In each industrial and agricultural context, therefore, singular guidelines should be discussed and elaborated, with wide dissemination of the benefits of changing perspectives. The adoption of public prizes, green stamps and tactics of differentiation between the new and the old model stand as one of the possibilities to change the old behavior based on the excessive exploitation of natural resources. An example of this happens in the incentive of the practices of zero residue that aligns with the model of circular economy and must have public protagonism. From the principles of the circular economy is that the public choices must debate the economic and financial decisions, that is, they become the sphere of the undecidable with regard to environmental protection. They are part of a model of national and international governance that fosters collaboration among green companies capable of establishing a new way of relating productive activity to sustainability. It is a path with no return that requires voluntary adherence or inhibition of deviant behavior, increasingly from the state force, consisting of sanctions of the most varied forms [3].

It should also be noted the prominent role of governments and funding agencies in adopting transition guidelines for the circular economy. The specificity of local conditions, especially in the case of economically disadvantaged countries, requires consistent, stable and strong enough action to encourage a shift in environmental policy. It is also associated with the publicity of the economic, financial and industrial agents already adhering to the circular economy movement. The various strategic actions must be guided by the conditions of impulse of those who reverse the logic of exploitation, operate cooperatively and act in accordance with the principles of circular economy. Without this, individual actions lose their breath in the face of the market that still operates in the old logic of the excessive exploitation of natural resources. The implementation of a wave of circular economy, therefore, presupposes stable, long-term commitments with state guarantees assessed by other internal and external economic agents, through governance [3].

The United Nations (UN) international policy management plays a decisive role in shifting internal and international management through the production of newsletters, mandatory guidelines, development objectives and sustainability, most of which are present in Agenda 2030. Countries they also rely on the European Commission's management model which has been working to promote initiatives in the member countries leading to 
sustainability objectives, including production, consumption, management of solid waste and the market for secondary raw materials, synthesized by: extract-make-use-delete. In this sense, from a theoretical point of view, the guidelines are established and the challenge of implementation is the task of all inhabitants of planet earth who do not think only in themselves and are capable of acting cooperatively [3].

\section{FINAL CONSIDERATIONS}

Excessive exploitation of natural resources, including water, puts the human survival on the planet at risk. Since the 1970s, pollution and scarcity of resources from industrialization and urban growth have worried the countries of the world, and the idea of an environment with infinite and limitless resources has given way to the idea of sustainability.

In this context, the need to transition from the linear model of production and consumption, based on the principles of take, make, waste to circular economy, was considered as a holistic, restorative and regenerative model [4], including the use of water. State action is essential in the promotion of international agreements and treaties that establish uniform mechanisms for accreditation of fomented practices, fines and benefits arising from joining - or not - this movement. In order to do so, it is necessary to recognize the assumption accepted by the Microeconomics that the individual is an optimizing agent of costs and benefits, creating transnational mechanisms capable of encouraging individual and corporate behavior in accordance with the guidelines of the circular economy.

\section{REFERENCES}

[1] Sirvinskas, L.P., Manual de Direito Ambiental, Saraiva: São Paulo, p. 399, 2017.

[2] Bosselmann, K., O princípio da sustentabilidade: transformando direito $e$ governança, Revista dos Tribunais: São Paulo, p. 104, 2015.

[3] Lacy, P. \& Rutqvist, J., Waste to Wealth: Creating Advantage in a Circular Economy, Palgrave Macmillan: London, 2015.

[4] Espaliat, M., Economia circular y Sostenibilidad: Nuevos Enfoques para la Creación de Valor, Spain, 2017.

[5] Aragão, A., Direito Constitucional do Ambiente na União Europeia. Direito Constitucional Ambiental, eds J.J.G. Canotilho \& J.R.M. Leite, Saraiva: São Paulo, 2011.

[6] Ferrer, G., La Construcción del Derecho Ambiental. Revista Novos Estudos Jurídicos, 18(3), 2013. https://siaiap32.univali.br/seer/index.php/nej/article/view/5128/2688. Accessed on: 3 Jan. 2018.

[7] Ferrer, G. et al., Sustentabilidade: um novo paradigma para o Direito. Revista Novos Estudos Jurídicos, 19(4), 2014. https://siaiap32.univali.br/seer/index.php/nej/article/ view/6712/3833. Accessed on: 3 Jan. 2018.

[8] Silva, G.E.N., Direito Ambiental Internacional: meio ambiente, desenvolvimento sustentável e os desafios da nova ordem mundial, Thex: Rio de Janeiro, 1995.

[9] Melgarejo, J., La reutilización del agua em el marco de la economia circular. https://iuaca.ua.es/es/documentos/documentos/prensa/2017-joaquin-melgarejo-eleconomista.pdf. Accessed on: 3 Jan. 2018.

[10] Mankiw, N.G., Princípios de Microeconomia, Cangage Learning: São Paulo, 2016.

[11] Ramos, A.L.S. \& Rosa, A.M., O problema cognitivo do discurso da Sustentabilidade, Alicante, Spain, 2017.

[12] Cooter, R. \& Ulen, R., Direito \& Economia, Bookman: Porto Alegre, 2010.

[13] Galdino, F., Introdução à Teoria dos Custos dos Direitos: Direitos não nascem em árvores, Lumen Juris: Rio de Janeiro, 2005, p. 209. 
[14] Hardin, G., The tragedy of the commons. Science, 162, pp. 1243-1248, 1968.

[15] Marinho, R., Prática na Teoria: aplicações da teoria dos jogos e da evolução aos negócios, Saraiva: São Paulo, p. 195, 2011.

[16] Marcelino Jr., J.C., Análise Econômica do Acesso à Justiça: a tragédia dos custos e a questão do acesso inautêntico, Lumen Juris: Rio de Janeiro, pp. 156-160, 2016.

[17] Coase, R.H., The Firm, the Market, and the Law, University of Chicago Press: Chicago, 1990.

[18] Bierman, H.S. \& Fernandez, L., Teoria dos Jogos, Person Prentice Hall: São Paulo, p. 70, 2011.

[19] Giko Jr., I.T., A Tragédia do Judiciário. Revista de Direito Administrativo, 267, p. 179, Sep./Dec. 2014.

[20] Agustinho, E.O., As Tragédias dos Comuns e dos Anticomuns. O que é Análise Econômica do Direito: uma introdução, eds M.C.P. Ribeiro \& V. Klein, Fórum: Belo Horizonte, p. 52, 2011.

[21] European Commission. http://europa.eu/rapid/press-release_MEMO-15-6204_pt.htm.

[22] Bachelet, M., Ingerência ecológica: Direito Ambiental em Questão, Piaget: Lisboa, 1995, p. 185-260.

[23] Pillet, G., Economia Ecológica: introdução à economia do ambiente e recursos naturais, Piaget: Lisboa, 1993. 